\title{
UPAYA MENINGKATKAN KETERAMPILAN SISWA MEMAINKAN ALAT MUSIK ANGKLUNG MELALUI METODE PEMBELAJARAN LANGSUNG
}

\author{
Wirda Hayati \\ UPTD SMPN 5 Kecamatan Lareh Sago Halaban, Kabupaten Lima Puluh Kota \\ email: hjina0324@gmail.com
}

\begin{abstract}
The purpose of this study was to see that using direct learning methods could improve students' skills in using Angklung musical instruments for class VIII.B UPTD SMP Negeri 5 Lareh Sago Halaban in the 2019/2020 academic year. This type of research is a classroom action research. The subjects in this study were students of class VIII.B UPTD SMPN 5 Lareh Sago Halaban District, 2019/2020 academic year which consisted of 16 students consisting of 7 female students and 9 male students. This research was conducted in two cycles, where each cycle consisted of three meetings. From the results of the data analysis, it was obtained that the average mastery of students was as follows in cycle I which applied direct learning methods, students who were in the less category increased to 77.31 but had not met the criteria that needed to be seen with action in cycle 2 . By application The direct learning method in playing the Angklung musical instrument in cycle 2, all students are in the good category with a score of 82.19. From the analysis of the data obtained, it is concluded that the learning method can improve the skills to play the Angklung musical instrument in class VIII.B UPTD SMPN 5 Lareh Sago HalabanDistrict in the 2019/2020 academic year.

Keywords: Student Skills, Angklung Musical Instruments, Direct Method
\end{abstract}

\begin{abstract}
ABSTRAK
Tujuan penelitian ini adalah untuk mengetahui penggunaan metode pembelajaran langsung dapat meningkatkan keterampilan siswa dalam menggunakan alat musik angklung kelas VIII.B UPTD SMP Negeri 5 Lareh Sago Halaban tahun pelajaran 2019/2020. Jenis penelitian ini adalah penelitian tindakan kelas. Subjek dalam penelitian ini adalah siswa kelas VIII.B UPTD SMPN 5 Kecamatan Lareh Sago Halaban tahun pelajaran 2019/2020 yang berjumlah 16 siswa yang terdiri dari 7 siswa perempuan dan 9 siswa laki laki. Penelitian ini dilaksanakan sebanyak dua siklus, dimana setiap siklus terdisi dari dua kali pertemuan. Dari hasil analisa data diperoleh rata-rata penguasaan peserta didik adalah sebagai berikut pada siklus I diterapkan metode pembelajaran langsung, siswa yang berada dalam kategori kurang meningkat menjadi 77,31 tetapi belum memenuhi kriteria keberhasilan sehingga perlu dilanjutkan dengan tindakan pada siklus 2 . Dengan penerapan metode pembelajaran langsung dalam memainkan alat musik angklung pada siklus 2 ini, seluruh siswa berada dalam kategori baik dengan nilai rata-rata 82,19. Dari pengamatan dan analisis data yang diperoleh, disimpulkan bahwa metode pembelajaran langsung dapat meningkatkan keterampilan memainkan alat musik angklung pada siswa kelas VIII.B UPTD SMPN 5 Kecamatan Lareh Sago Halaban tahun pelajaran 2019/2020.
\end{abstract}

Kata kunci: Keterampilan Siswa, Alat Musik Angklung, Metode Langsung. 


\section{PENDAHULUAN}

Pendidikan Nasional yang bertujuan mencerdaskan bangsa serta membentuk pribadi yang beretika, berilmu pengetahuan serta mempunyai keterampilan. Hal ini adalah perwujudan dari pengamalan Pancasila dan UUD 1945. Pendidikan berjenjang selama 9 tahun yang wajib diikuti oleh peserta didik anak anak Indonesia adalah bukti bahwasanya Pendidikan di Indonesia mempunyai karakter yang mengedepankan proses pendidikan berkelanjutan.

Pendidikan yang berkelanjutan tersebut diharapkan memicu semangat dan diharapkan menjadi bekal bagi mereka dalam belajar dan memperoleh ilmu pengetahuan serta keterampilan bagi masa depan peserta didik. Ilmu yang diwajibkan bagi peserta didik bukan hanya dibidang pengetahuan yang memacu kecerdasan otak kanan saja tetapi juga menekankan kepada kecerdasan otak kiri yang nota bene adlah untuk memacu kreatifitas serta keterampilan berdasarkan bakat dan minat peserta didik itu sendiri. Maka untuk mempermudah dalam penyampaian ilmu kepada peserta didik oleh pemerintah disusun kurikulum yang sesuai dengan perkembangan pendidikan itu sendiri serta disesuaikan dengan karakter bangsa Indonesia, diantara kurikulum yang sampai sekarang masih berlaku adalah kurikulum yang berbasis kepada kompetensi. Kurikulum ini dirancang untuk memberikan pengalaman belajar seluas luasnya kepada peserta didik serta dapat mengembangkan kemampuan bersikap, berpengetahuan, berketerampilan dan bertindak.

Keterampilan tidak bisa dipisahkan dari tujuan pendidikan, dalam hal ini mata pelajaran seni budaya sebagai mata pelajaran wajib di Sekolah Menengah merupakan pengalaman belajar untuk mencapai keahlian berkesenian sebagai perwujudan ekspresi peserta didik. Pada mata pelajaran seni budaya ada beberapa keterampilan yang dituntut untuk dipahami oleh peserta didik, tetapi dalam hal ini keterampilan yang dimaksud adalah keterampilan bermusik khususnya dalam mempergunakan alat musik angklung oleh siswa VIII.B UPTD SMP Negeri 5 Lareh Sago Halaban. Keterampilan dalam menggunakan alat musik ini bertujuan agar peserta didik terampil dalam mengekspresikan jiwa berkeseniannya.

Namun, pada hakikatnya belajar mengajar adalah suatu proses interaksi antara guru dengan siswa dalam suatu pembelajaran. Guru dalam komponen belajar mengajar mempunyai peran yang sangat penting. Guru bukan saja hanya penyampai materi saja materi namun lebih dari itu guru dapat dikatakan sebagai sentral pembelajaran. Guru memiliki tugas yang sangat berat untuk tercapainya tujuan pendidikan nasional dan meningkatkan kualitas manusia Indonesia, manusia seutuhnya yang bertaqwa kepada Tuhan Yang Maha Esa.

Pembelajaran menggunakan salah satu alat musik (angklung). Menurut Rosyadi (2002) angklung adalah alat musik tradisional Indonesia yang berasal dari tanah Sunda, terbuat dari bambu, yang dibunyikan dengan cara digoyangkan. Menggunakan alat musik angklung merupakan kompetensi yang diharapkan bisa dimiliki oleh peserta didik kelas VIII.B. Hal ini adalah, modal dasar bagi mereka untuk mempergunakan secara mahir pada kelas berikutnya, sehingga dengan demikian rasa bermusik atau kepekaan mereka terhadap musik akan terlatih dengan benar dan cermat. Tetapi kenyataan yang dihadapi dilapangan adalah masih banyaknya peserta didik yang belum terampil bahkan tidak bisa memnggunakan salah satu alat musik terutama pada alat musik angklung. Hal ini disebabkan rasa bermusik mereka belum terlatih serta 
kurangnya latihan dan ketidak tahuan peserta terhadap cara atau teknik menggunakan alat musik angklung (alat musik tradisional nusantara). Selain hal diatas faktor yang menyebabkan peserta didik belum mampu adalah belum adanya ketertarikan peserta didik dalam mata pelajaran seni budaya terutama dalam menggunakan alat musik angklung. Peserta didik yang ingin terampil dalam menggunakan alat musik angklung tidak cukup dengan mempelajari tentang teknik. Karena keterampilan dalam mengunakan alat musik angklung merupakan proses pertumbuhan melalui banyak praktek dan latihan yang teratur.

Menurut Arends (Trianto, 2010:41) model pembelajaran langsung adalah salah satu pendekatan mengajar yang dirancang khusus untuk menunjang proses belajar siswa yang berkaitan dengan pengetahuan deklaratif dan pengetahuan prosedural yang terstruktur dengan baik yang dapat diajarkan dengan pola kegiatan bertahap. Amri dan Ahmadi (2010:39) menjelaskan bahwa metode pembelajaran langsung merupakan salah satu model pengajaran yang dirancang khusus untuk mengembangkan belajar siswa tentang pengetahuan prosedural dan pengetahuan deklaratif yang terstruktur dengan baik dan dapat dipelajari selangkah demi selangkah. Kasmaja (2014) menjelaskan bahwa kelemahan metode pembelajaran langsung adalah siswa memiliki sedikit kesempatan untuk terlibat secara aktif dan jika gaya komunikasi guru buruk cenderung menghasilkan pembelajaran yang buruk pula.

Berdasarkan permasalahan permasalahan di atas maka penulis sangat tertarik untuk mengupas tentang hal ini dan berminat melaksanakan penelitian berupa kegiatan pembelajaran tentang keterampilan menggunakan alat musik angklung. Dan penulis akan melaksanakan praktek keterampilan bermusik yang mempergunakan alat musik angklung di kelas VIII/B.

Dari latar belakang diatas maka harus diadakan Penelitian Tindakan Kelas (PTK) yang diharapkan dapat menambah wawasan serta keterampilan peserta didik khususnya mata pelajaran Seni Budaya. Penelitian Tindakan Kelas ini diberi judul "Upaya Meningkatkan Keterampilan Siswa dalam memainkan alat musik angklung melalui metode pembelajaran langsung".

\section{METODOLOGI}

Jenis penelitian ini adalah Penelitian Tindakan Kelas (PTK). Penelitian yang dilaksanakan ini merupakan penelitia tindakan sekolah, dan dilaksanakan Subjek dalam penelitian ini adalah siswa kelas VIII.B UPTD SMPN 5 Kecamatan Lareh Sago Halaban tahun pelajaran 2019/2020 yang berjumlah 16 siswa yang terdiri dari 7 siswa perempuan dan 9 siswa laki laki. Penelitian ini dilaksanakan sebanyak dua siklus, dimana setiap siklus terdisi dari dua kali pertemuan. Instrumen yang digunakan dalam penelitian ini adalah lembar observasi aktivitas guru dan siswa, catatan harian, dan lembar penilaian tes praktek.

Kriteria penilaian untuk tes praktek dapat dilihat pada Tabel 1 berikut.

Tabel 1. Kriteria Penilaian Untuk Tes Praktek

\begin{tabular}{|l|l|l|l|l|}
\hline No & Indikator & Skor & Keterangan & \multicolumn{1}{c|}{ Rubrik Penilaian } \\
\hline 1 & $\begin{array}{l}\text { Ketepatan } \\
\text { Nada }\end{array}$ & 40 & Sangat Baik & $\begin{array}{l}\text { Dapat memainkan nada pada } \\
\text { angklung dengan lagu bubuy bulan } \\
\text { dengan benar dan tepat sesuai } \\
\text { tempo, durasi, dan dinamik }\end{array}$ \\
\hline & & 30 & Baik & Dapat memainkan angklung lagu \\
\hline
\end{tabular}




\begin{tabular}{|c|c|c|c|c|}
\hline No & Indikator & Skor & Keterangan & Rubrik Penilaian \\
\hline & & & & $\begin{array}{l}\text { dengan benar sesuai tempo dan } \\
\text { durasi }\end{array}$ \\
\hline & & 20 & Kurang & $\begin{array}{l}\text { Dapat memainkan angklung lagu } \\
\text { Bubuy Bulan dengan benar sesuai } \\
\text { tempo }\end{array}$ \\
\hline & & 10 & $\begin{array}{l}\text { Sangat } \\
\text { Kurang }\end{array}$ & $\begin{array}{l}\text { Belum dapat memegang angklung } \\
\text { dengan benar }\end{array}$ \\
\hline \multirow[t]{4}{*}{2} & Ritmis & 40 & Sangat Baik & $\begin{array}{l}\text { Dapat memainkan angklung } \\
\text { dengan benar dan tepat sesuai } \\
\text { tempo dan aksen serta ekspresi }\end{array}$ \\
\hline & & 30 & Baik & $\begin{array}{l}\text { Dapat memainkan angklung (lagu } \\
\text { bubuy bulan) dengan benar sesuai } \\
\text { tempo dan aksen }\end{array}$ \\
\hline & & 20 & Kurang & $\begin{array}{l}\text { Dapat memainkan angklung (lagu } \\
\text { bubuy bulan) dengan benar sesuai } \\
\text { tempo }\end{array}$ \\
\hline & & 10 & $\begin{array}{l}\text { Sangat } \\
\text { Kurang }\end{array}$ & $\begin{array}{l}\text { Belum dapat memaikan angklung } \\
\text { (lagu Bubuy Bulan) dengan benar }\end{array}$ \\
\hline \multirow[t]{4}{*}{3} & $\begin{array}{l}\text { Teknik } \\
\text { Bermain }\end{array}$ & 40 & Sangat Baik & $\begin{array}{l}\text { Dapat memainkan angklung dengan } \\
\text { benar dan memegang angklung } \\
\text { dengan posisi yang benar }\end{array}$ \\
\hline & & 30 & Baik & $\begin{array}{l}\text { Dapat memainkan angklung tetapi } \\
\text { posisi memegang tidak tepat }\end{array}$ \\
\hline & & 20 & Kurang & $\begin{array}{l}\text { Dapat membunyikan angklung } \\
\text { tetapi kurang tepat }\end{array}$ \\
\hline & & 10 & $\begin{array}{l}\text { Sangat } \\
\text { Kurang }\end{array}$ & $\begin{array}{l}\text { Belum dapat bermain angklung } \\
\text { dengan tepat dan benar }\end{array}$ \\
\hline \multirow[t]{4}{*}{4} & Kekompakan & 40 & Sangat Baik & $\begin{array}{l}\text { Dapat memainkankan angklung } \\
\text { (lagu Bubuy Bulan) dengan } \\
\text { angklung secara berkelompok } \\
\text { dengan nada, ritmis dan teknik } \\
\text { yang tepat dan benar }\end{array}$ \\
\hline & & 30 & Baik & $\begin{array}{l}\text { Dapat memainkan angklung ( lagu } \\
\text { bubuy bulan) dengan angklung } \\
\text { berkelompok sesuai nada dan } \\
\text { teknik yang tepat }\end{array}$ \\
\hline & & 20 & $\begin{array}{l}\text { Kurang } \\
\text { Baik }\end{array}$ & $\begin{array}{l}\text { Dapat memainkan angklung (lagu } \\
\text { Bubuy Bulan) berkelompok sesuai } \\
\text { teknik }\end{array}$ \\
\hline & & 10 & $\begin{array}{l}\text { Sangat } \\
\text { Kurang }\end{array}$ & $\begin{array}{l}\text { Belum dapat memainkan angklung } \\
\text { dengan lagu Bubuy Bulan secara } \\
\text { berkelompok }\end{array}$ \\
\hline
\end{tabular}

Untuk total skor atau nilai akhir keterangan kriterian penilaian dapat dilihat pada Tabel 2 berikut. 
Tabel 2. Rentang Nilai Penentuan Penilaian

\begin{tabular}{|c|c|c|}
\hline NO & NILAI & KETERANGAN \\
\hline 1 & $86-100$ & Sangat Baik \\
\hline 2 & $80-85$ & Baik \\
\hline 3 & $72-79$ & Cukup \\
\hline 4 & $62-71$ & Kurang \\
\hline 5 & $50-61$ & Sangat Kurang \\
\hline
\end{tabular}

Kriteria keberhasilan dalam penelitian ini yaitu jika nilai rata-rata dalam kategori "Baik", jika tidak maka penelitian dilanjutkan ke siklus berikutnya.

\section{HASIL PENELITIAN DAN PEMBAHASAN}

\section{Pra siklus}

Sebelum dilakukan tindakan penelitian, terlebih dahulu dilakukan penilaian untuk mengetahui seberapa jauh keterampilan siswa dalam memainkan alat musik angklung. Hasil pra siklus dapat dilihat pada Tabel 3 berikut.

Tabel 3. Hasil Tes Pra Siklus

\begin{tabular}{|c|c|c|c|c|c|c|c|}
\hline No & Nama & $\begin{array}{l}\mathrm{Na} \\
\mathrm{da}\end{array}$ & $\begin{array}{l}\text { Rit } \\
\text { me }\end{array}$ & $\begin{array}{l}\text { Teknik } \\
\text { Bermain }\end{array}$ & $\begin{array}{l}\text { Kekom } \\
\text { pakan }\end{array}$ & $\begin{array}{l}\text { Jum } \\
\text { lah }\end{array}$ & Ket. \\
\hline 1 & Abdullah Ammar & 20 & 20 & 20 & 25 & 65 & Kurang \\
\hline 2 & Adis Afrian & 20 & 20 & 20 & 15 & 80 & Baik \\
\hline 3 & Aldi & 20 & 20 & 20 & 15 & 80 & Baik \\
\hline 4 & Bunga. R & 20 & 20 & 20 & 20 & 60 & $\begin{array}{l}\text { Sangat } \\
\text { Kurang }\end{array}$ \\
\hline 5 & Diva Alzahra & 20 & 20 & 15 & 25 & 80 & Baik \\
\hline 6 & Doni Ardiansyah & 15 & 15 & 20 & 20 & 60 & $\begin{array}{l}\text { Sangat } \\
\text { Kurang }\end{array}$ \\
\hline 7 & Femas Ardiansyah & 20 & 15 & 20 & 20 & 55 & $\begin{array}{l}\text { Sangat } \\
\text { Kurang }\end{array}$ \\
\hline 8 & Lastri Syifa Agusti & 20 & 15 & 20 & 25 & 65 & Kurang \\
\hline 9 & Lisa Putri Ningsih & 20 & 20 & 20 & 20 & 65 & Kurang \\
\hline 10 & M.Rafli Ismail & 20 & 15 & 20 & 20 & 60 & $\begin{array}{l}\text { Sangat } \\
\text { Kurang }\end{array}$ \\
\hline 11 & Nola Belia & 20 & 20 & 20 & 25 & 50 & $\begin{array}{l}\text { Sangat } \\
\text { Kurang }\end{array}$ \\
\hline 12 & Qiara Fahmadilla & 20 & 20 & 20 & 25 & 60 & $\begin{array}{l}\text { Sangat } \\
\text { Kurang }\end{array}$ \\
\hline 13 & Syarah Rahma.J & 15 & 20 & 20 & 20 & 50 & $\begin{array}{l}\text { Sangat } \\
\text { Kurang }\end{array}$ \\
\hline 14 & Suhada Akum & 15 & 15 & 20 & 20 & 60 & $\begin{array}{l}\text { Sangat } \\
\text { Kurang }\end{array}$ \\
\hline 15 & Tito Satria & 15 & 20 & 15 & 20 & 65 & Kurang \\
\hline 16 & Hafiz & 15 & 15 & 20 & 20 & 60 & $\begin{array}{l}\text { Sangat } \\
\text { Kurang }\end{array}$ \\
\hline & & & & Total & & $\begin{array}{l}1015 \\
63,4\end{array}$ & \\
\hline
\end{tabular}


Berdasarkan hasil tes pada pra siklus yang menunjukkan rata-rata nilai 63,44 dengan kategori kurang, maka perlu dilakukan tindakan yaitu dengan menerapkan metode pembelajaran langsung.

\section{Siklus 1}

1) Perencanaan Penelitian Tindakan

a) Menyiapkan instrumen penelitian yaitu lembar observasi aktivitas siswa dan guru yang digunakan untuk mencatat hasil pengamatan selama pelaksanaan pembelajaran, dan instrumen penilaian tes praktek angklung.

b) Peneliti menyiapkan 2 set alat musik angklung sebagai media pembelajaran angklung. Berdasarkan jumlah siswa sebanyak 16 siswa.

c) Menyiapkan notasi angka lagu "Bubuy Bulan" yang akan ditulis di white board untuk membantu siswa agar mudah membacanya.

2) Pelaksanaan

Pelaksanaan pembelajaran siklus I dilakukan 3 kali pertemuan yaitu dua pertemuan tatap muka dan satu kali tes. pada hari Senin tanggal 13 dan 20 Januari 2020 jam pelajaran ke 2, 3 dan 4. 1 jam pelajaran 40 menit. Jadi waktu pelaksanaan pada pertemuan I adalah 3 X 40 menit. Pertemuan 3 berlangsung pada hari Senin tanggal 27 Januari 2020 dilaksanakan tes praktek dengan durasi yang sama. Berikut adalah langkah-langkah yang dilaksanakan pada saat pembelajaran:

- Kegiatan Awal

a) Memberi salam, berdo'a dan menyanyikan salah satu lagu Nasional

b) Apersepsi

c) Guru memainkan alat musik angklung dengan standar. Materi lagu yang dimainkan adalah "Bubuy Bulan" dan siswa mendengarkan

d) Membagi jumlah siswa atas dua kelompok yang masing-masing siswa memegang satu angklung dengan nada yang berurutan

- Kegiatan Inti

a) Memberikan contoh cara memegang alat musik angklung yang baik dan benar dan mengajari langsung kepada siswa cara membunyikan atau memainkan alat musik angklung dengan benar agar kualitas suara yang dihasilkan sesuai dengan yang diharapkan.

b) Mengatur tempat siswa sesuai dengan nada angklung yang dipegangnya agar memudahkan untuk menyelaraskan bunyi

c) Melakukan pemanasan secara bersama membunyikan angklung serentak dengan nada yang ditentukan oleh guru atau mengikuti gerak jenjang paranada, hal ini penting untuk memperoleh nada yang baik dan gerakan yang sama serta tidak terputus. Lalu secara bersama memainkan notasi yang ditunjuk oleh guru diwhiteboard dengan tangga nada $\mathrm{C}$ mayor.

d) Siswa diminta secara perorangan membaca notasi angka yang ditunjuk oleh guru di whiteboard

e) Memainkan lagu "Bubuy Bulan" menggunakan angklung dengan tempo lambat, kegiatan ini dibantu oleh guru dengan menunjukkan notasi angka yang sebelumnya sudah ditulis di whiteboard. Konsentrasi siswa kepada angklung dan konsentrasi mata tetap pada 
notasi angka yang ditunjuk oleh guru dengan alat bantu. Lagu dimainkan perbaris agar siswa dapat mudah menghafal notasinya.

f) Siswa memainkan alat musik angklung dengan materi lagu "Bubuy Bulan" dengan tempo agak dipercepat. Pada tahap ini siswa diminta memainkankan lagu perdua baris, lalu dari awal sampai akhir.

g) Siswa diminta secara perorangan untuk menyanyikan syar lagu "Bubuy Bulan" yang ditunjuk oleh guru di whiteboard.

- Kegiatan Akhir

a) Guru kembali memperagakan permainan alat musik angklung dihadapan siswa dengan memakai standar.

b) Mengevaluasi siswa yang masih perlu banyak latihan serta memberikan penghargaan kepada siswa yang sudah benar memainkan alat musik angklung.

c) Menyimpulkan secara bersama tentang kesimpulan pembelajaran hari ini

d) Memberi kesempatan kepada siswa untuk bertanya seputar pembelajaran angklung yang baru saja dilaksanakan. Siswa daoat melontarkan pertanyaan mengenai pembelajaran angklung, dan pertanyaan hanya dibatasi tentang permainan alat musik angklung.

e) Menginformasikan kegiatan yang akan dilakukan pada pertemuan berikutnya.

f) Berdo'a

g) Salam

Pada pertemuan terakhir siklus I ini dilakukan tes. Tes dilakukan perkelompok angklung yang sudah ditetapkan. Setelah dilakukan tes, hasil tes siklus I dapat dilihat pada tabel berikut :

Tabel 4. Hasil Siklus I

\begin{tabular}{|c|c|c|c|c|c|c|c|}
\hline No & Nama & $\begin{array}{l}\mathrm{Na} \\
\mathrm{da}\end{array}$ & $\begin{array}{l}\text { Rit } \\
\text { me }\end{array}$ & $\begin{array}{l}\text { Teknik } \\
\text { Bermain }\end{array}$ & $\begin{array}{l}\text { Kekom } \\
\text { pakan }\end{array}$ & $\begin{array}{l}\text { Jum } \\
\text { lah }\end{array}$ & Ket. \\
\hline 1 & Abdullah Ammar & 20 & 20 & 20 & 25 & 75 & Cukup \\
\hline 2 & Adis Afrian & 20 & 20 & 20 & 15 & 85 & Baik \\
\hline 3 & Aldi & 20 & 20 & 20 & 15 & 82 & Baik \\
\hline 4 & Bunga. R & 20 & 20 & 20 & 20 & 80 & Baik \\
\hline 5 & Diva Alzahra & 20 & 20 & 15 & 25 & 80 & Baik \\
\hline 6 & Doni Ardiansyah & 15 & 15 & 20 & 20 & 70 & Kurang \\
\hline 7 & Femas Ardiansya & 20 & 15 & 20 & 20 & 75 & Cukup \\
\hline 8 & Lastri Syifa Agust & 20 & 15 & 20 & 25 & 80 & Baik \\
\hline 9 & Lisa Putri Ningsih & 20 & 20 & 20 & 20 & 80 & Baik \\
\hline 10 & M.Rafli Ismail & 20 & 15 & 20 & 20 & 75 & Cukup \\
\hline 11 & Nola Belia & 20 & 20 & 20 & 25 & 85 & Baik \\
\hline 12 & Qiara Fahmadilla & 20 & 20 & 20 & 25 & 85 & Baik \\
\hline 13 & Syarah Rahma.J & 15 & 20 & 20 & 20 & 75 & Cukup \\
\hline 14 & Suhada Akum & 15 & 15 & 20 & 20 & 70 & Kurang \\
\hline 15 & Tito Satria & 15 & 20 & 15 & 20 & 70 & Kurang \\
\hline 16 & Hafiz & 15 & 15 & 20 & 20 & 70 & Kurang \\
\hline & & & & \multicolumn{2}{|l|}{ Jumlah } & 1237 & \\
\hline & & & & \multicolumn{2}{|l|}{ Rata-rata } & 77,3 & \\
\hline
\end{tabular}


Berdasarkan tabel 4 jumlah Skor keseluruhan pada tes siklus berjumlah 1237 yang berarti meningkat dari prasiklus. Berdasarkan hasil penilaian siklus I, nilai rata-rata siswa yaitu sebesar 77,31 dengan kategori cukup.

3) Observasi

Observasi dilakukan ketika pelaksanaan tindakan diberikan oleh peneliti. Alat yang dipakai adalah lembar observasi yang digunakan untuk mencatat perkembangan yang terjadi pada pembelajaran alat musik angklung siswa kelas VIII.B Semester Genap Tahun pelajaran 2019/2020 UPTD SMPN 5 Kecamatan Lareh Sago Halaban. Hasil observasi kegitan guru adalah sebagai berikut

\section{Tabel 5. Hasil Aktivitas Guru Siklus I}

\begin{tabular}{|c|c|c|c|}
\hline \multirow{2}{*}{ No. } & \multirow{2}{*}{ Aktivitas Guru } & \multicolumn{2}{|c|}{ Pertemuan } \\
\hline & & 1 & 2 \\
\hline 1 & $\begin{array}{l}\text { Memberikan contoh cara memegang alat musik } \\
\text { angklung yang baik dan benar }\end{array}$ & $\sqrt{ }$ & $\sqrt{ }$ \\
\hline 2 & $\begin{array}{l}\text { Mengajari langsung kepada siswa cara membunyikan } \\
\text { atau memainkan alat musik angklung dengan benar }\end{array}$ & $\sqrt{ }$ & $\sqrt{ }$ \\
\hline 3 & $\begin{array}{l}\text { Mengatur tempat siswa sesuai dengan nada angklung } \\
\text { yang dipegangnya agar memudahkan untuk } \\
\text { menyelaraskan bunyi }\end{array}$ & $\sqrt{ }$ & $\sqrt{ }$ \\
\hline 4 & Melakukan pemanasan secara bersama & $\sqrt{ }$ & $\sqrt{ }$ \\
\hline 5 & $\begin{array}{l}\text { Meminta siswa secara perorangan membaca notasi } \\
\text { angka yang ditunjuk diwhiteboard }\end{array}$ & $\sqrt{ }$ & $\sqrt{ }$ \\
\hline 6 & $\begin{array}{l}\text { Meminta siswa Memainkan lagu "Bubuy Bulan" } \\
\text { menggunakan angklung dengan tempo lambat }\end{array}$ & $\sqrt{ }$ & $\sqrt{ }$ \\
\hline 7 & $\begin{array}{l}\text { Meminta siswa memainkan alat musik angklung dengan } \\
\text { materi lagu "Bubuy Bulan" dengan tempo agak } \\
\text { dipercepat }\end{array}$ & $\sqrt{ }$ & $\sqrt{ }$ \\
\hline 8 & $\begin{array}{l}\text { Meminta siswa secara perorangan untuk menyanyikan } \\
\text { syar lagu "Bubuy Bulan" yang ditunjuk oleh guru } \\
\text { diwhiteboard }\end{array}$ & $\sqrt{ }$ & $\sqrt{ }$ \\
\hline 9 & $\begin{array}{l}\text { Memperagakan permainan alat musik angklung } \\
\text { dihadapan siswa dengan memakai standar. }\end{array}$ & & $\sqrt{ }$ \\
\hline \multicolumn{2}{|r|}{ Jumlah } & 8 & 9 \\
\hline \multicolumn{2}{|c|}{ Persentase } & $89 \%$ & $100 \%$ \\
\hline
\end{tabular}

Hasil observasi aktivitas siswa pada siklus I dapat dilihat pada tabel 6 sebagai berikut.

Tabel 6. Hasil Aktivitas Siswa Siklus I

\begin{tabular}{|l|l|c|c|c|c|}
\hline \multirow{2}{*}{ No. } & \multicolumn{1}{|c|}{ Aktivitas Siswa } & \multicolumn{2}{c|}{ Banyak Siswa } & \multicolumn{2}{c|}{ Persentase } \\
\cline { 3 - 6 } & \multicolumn{1}{|l}{$\begin{array}{l}\text { Pert. 1 } \\
\text { Memperhatikan penjelasan guru } \\
\text { secara detil tentang teknik dan } \\
\text { etika bermain angklung }\end{array}$} & & Pert. 1 & Pert. 2 \\
\hline 2 & $\begin{array}{l}\text { Memegang angklung dengan } \\
\text { benar }\end{array}$ & 8 & 12 & $50.0 \%$ & $75.0 \%$ \\
\hline
\end{tabular}


4) Refleksi

\begin{tabular}{|l|l|c|c|c|c|}
\hline \multirow{2}{*}{ No. } & \multicolumn{1}{|c|}{ Aktivitas Siswa } & \multicolumn{2}{c|}{ Banyak Siswa } & \multicolumn{2}{c|}{ Persentase } \\
\cline { 3 - 6 } & & Pert. 1 & Pert. 2 & Pert. 1 & Pert. 2 \\
\hline 3 & $\begin{array}{l}\text { Percaya diri memainkan alat } \\
\text { musik angklung }\end{array}$ & 9 & 13 & $56.3 \%$ & $81.3 \%$ \\
\hline 4 & $\begin{array}{l}\text { Fokus dalam memainkan } \\
\text { angklung }\end{array}$ & 9 & 12 & $56.3 \%$ & $75.0 \%$ \\
\hline 5 & $\begin{array}{l}\text { Kompak dengan kelompok dalam } \\
\text { memainkan angklung }\end{array}$ & 6 & 10 & $37.5 \%$ & $62.5 \%$ \\
\hline \multicolumn{1}{|l}{ Persentase } & $48 \%$ & $69 \%$ & & \\
\hline
\end{tabular}

Refleksi yang dimaksud adalah mengkaji apa yang telah terjadi pada pertemuan pertama tindakan siklus I, apa yang dihasilkan, kenapa hal tersebut terjadi, dan apa yang akan dilakukan selanjutnya. Pada pertemuan 1 siklus I ditemui hambatan dalam proses pembelajaran. Hambatan tersebut diantaranya adalah siswa masih canggung dan malu untuk memainkan angklung serta membunyikan tidak dengan teknik yang benar hal ini dikarenakan siswa belum mengenal alat musik angklung sehingga masih bingung untuk memainkannya. Beberapa siswa belum percaya diri dalam memegang angklung bahkan ada yang memegangnya dengan terbalik. Pada pertemuan 2 siklus I terlihat tidak ada lagi siswa yang memainkan angklung dengan terbalik. Dari refleksi tersebut menjadi acuan bagi peneliti untuk merancang teknik dan materi untuk perbaikan dan peningkatan keterampilan bermain instrumen alat musik angklung.

Perbaikan untuk siklus II yaitu sebagai berikut :

a) Peneliti menyiapkan 2 set alat musik angklung sebagai media pembelajaran, berdasarkan jumlah siswa sebanyak 16 orang seperti pada siklus I. Kali ini kelompok tetap dibagi 2 tetapi penempatannya agak berjauhan agar perkelompoknya bisa konsentrasi pada bunyi yang dihasilkan oleh kelompok mereka, hal ini untuk mengatasi agar mereka bisa lebih fokus dan terampil dalam memainkan alat musik angklung

b) Siswa menunjuk rekannya untuk menjadi pemandu notasi angka di whiteboard, setelah terlebih dahulu dipandu oleh guru dan siswa yang ditunujuk diminta memandu seperti apa yang sudah dilakukan oleh guru, hal ini dimaksudkan agar siswa tidak malu-malu untuk memainkan alat musik angklung dan pembelajaran dapat berlangsung dengan santai, sehingga kepercayaan diri mereka jadi terbangun.

c) Siswa diminta untuk bertanya tentang apa yang belum dimengerti, terutama tentang teknik bermain kepada guru, hal ini dimaksudkan supaya siswa mengerti dan paham karena guru memberikan penjelasan langsung secara prakteknya

\section{Siklus 2}

1) Perencanaan

Pada tahap ini rancangan tindakan adalah untuk perbaikan pada kendala-kendala yang ditemui pada siklus I. Perencanaan pada siklus II sebagai berikut : 
a) Menyiapkan instrumen penelitian yaitu lembar observasi aktivitas siswa dan guru yang digunakan untuk mencatat hasil pengamatan selama pelaksanaan pembelajaran, dan instrumen penilaian tes praktek angklung.

b) Peneliti menyiapkan 2 set alat musik angklung sebagai media pembelajaran, berdasarkan jumlah siswa sebanyak 16 orang seperti pada siklus I. Kali ini kelompok tetap dibagi 2 tetapi penempatannya agak berjauhan agar perkelompoknya bisa konsentrasi pada bunyi yang dihasilkan oleh kelompok mereka, hal ini untuk mengatasi agar mereka bisa lebih fokus dan terampil dalam memainkan alat musik angklung

c) Menyiapkan notasi angka lagu "Bubuy Bulan" yang akan ditulis di white board untuk membantu siswa agar mudah membacanya.

d) Mempersiapkan Rencana Pelaksanaan Pembelajaran (RPP).

2) Pelaksanaan

Pelaksanaan pembelajaran siklus II dilakukan 3 kali pertemuan yaitu dua pertemuan tatap muka dan satu kali tes. pada hari Senin tanggal 3 dan 10 Februari 2020 jam pelajaran ke 2, 3 dan 4. 1 jam pelajaran 40 menit. Jadi waktu pelaksanaan pada pertemuan I adalah 3 X 40 menit. Dan pertemuan 3 berlangsung pada hari Senin tanggal 17 Februari 2020 dilaksanakan tes juga dengan durasi yang sama. Berikut adalah langkah-langkah yang dilaksanakan pada saat pembelajaran:

- Kegiatan Awal (Pendahuluan)

a) Salam, berdo'a

b) Menyanyikan salah satu lagu nasional

c) Apersepsi

d) Membagi siswa menjadi dua kelompok, masing masing kelompok ditempat agak berjauhan dan masing masing kelompok membawa notasi angka yang ditulis dikertas ukuran 1,5 m

- Kegiatan Inti

a) Semua siswa memegang angklung, satu orang satu buah angklung

b) Dengan dikomandoi oleh guru siswa memegang angklung dengan teknik yang benar

c) Guru mencek satu persatu siswa dalam hal teknik memegang angklung dan membetulkan teknik kepada siswa yang salah tekniknya

d) Siswa secara serentak membunyikan angklung beberapa kali yang dikomandoi oleh guru

e) Guru menyanyikan "Bubuy Bulan" baik notasi angkanya maupun syairnya dan siswa mengikuti setelah guru

f) Guru memberikan contoh membunyikan angklung yang kemudian diikuti oleh siswa dikelompoknya masing- masing

g) Siswa diminta langsung memainkan angklung dengan materi lagu "Bubuy Bulan" secara berkelompok

h) Siswa diminta untuk memainkan lagu sesuai dengan tempo yang ada di notasi angka tersebut

i) Salah seorang siswa dari kelompok lain ditunjuk untuk memandu atau menunjuk notasi angka di whiteboard, secara bergantian

j) Guru kembali mengomandoi pergerakan bunyi angklung didepan , hal ini kembali berulangkali dilakukan pada setiap kelompok. 
k) Setiap kelompok secara bergantian dipandu dan dikomandoi oleh guru, ketika kelompok yang satu memainkan alat musik angklung maka kelompok yang lain mengamati

- Kegiatan Penutup

a) Mengevaluasi dengan cara mencek kepada setiap siswa agar bisa mengetahui siswa mana yang masih belum bisa memainkan alat musik angklung secara baik dan benar sesuai tekniknya. Hal ini dilakukan oleh guru kepada setiap siswa, guru mendekati dan meminta untuk membetulkan teknik sesuai arahan guru.

b) Memberi kesempatan siswa untuk bertanya seputar pembelajaran alat musik angklung

c) Menginformasikan kepada siswa bahwa pertemuan berikutnya adalah latihan perkelompok dan post tes

d) Menyanyikan salah satu lagu daerah

e) Do'a dan salam

Pada pertemuan 3 dilakukan tes siklus II. Test dilakukan dengan perkelompok yang sudah ditetapkan pada siklus II. Setelah dilakukan tes, hasilnya dapat dilihat pada tabel dibawah ini :

Tabel 7. Hasil Siklus II

\begin{tabular}{|c|c|c|c|c|c|c|c|}
\hline No & Nama & Nada & Ritme & $\begin{array}{l}\text { Teknik } \\
\text { Bermain }\end{array}$ & $\begin{array}{l}\text { Kekom } \\
\text { pakan }\end{array}$ & $\begin{array}{l}\text { Jum } \\
\text { lah }\end{array}$ & Ket. \\
\hline 1 & Abdullah Ammar & 20 & 20 & 20 & 25 & 80 & Baik \\
\hline 2 & Adis Afrian & 20 & 20 & 20 & 15 & 85 & Baik \\
\hline 3 & Aldi & 20 & 20 & 20 & 15 & 85 & Baik \\
\hline 4 & Bunga. $\mathrm{R}$ & 20 & 20 & 20 & 20 & 85 & Baik \\
\hline 5 & Diva Alzahra & 20 & 20 & 15 & 25 & 85 & Baik \\
\hline 6 & Doni Ardiansyah & 15 & 15 & 20 & 20 & 75 & Cukup \\
\hline 7 & Femas Ardiansya & 20 & 15 & 20 & 20 & 80 & Baik \\
\hline 8 & Lastri Syifa Agust & 20 & 15 & 20 & 25 & 80 & Baik \\
\hline 9 & Lisa Putri Ningsih & 20 & 20 & 20 & 20 & 85 & Baik \\
\hline 10 & M.Rafli Ismail & 20 & 15 & 20 & 20 & 80 & $\overline{\text { Baik }}$ \\
\hline 11 & Nola Belia & 20 & 20 & 20 & 25 & 85 & Baik \\
\hline 12 & Qiara Fahmadilla & 20 & 20 & 20 & 25 & 85 & Baik \\
\hline 13 & Syarah Rahma.J & 15 & 20 & 20 & 20 & 80 & Baik \\
\hline 14 & Suhada Akum & 15 & 15 & 20 & 20 & 85 & Baik \\
\hline 15 & Tito Satria & 15 & 20 & 15 & 20 & 80 & Baik \\
\hline 16 & Hafiz & 15 & 15 & 20 & 20 & 80 & Baik \\
\hline & & & & \multicolumn{2}{|c|}{ Total Skor } & 1315 & \\
\hline & & & & \multicolumn{2}{|c|}{ Rata-rata } & 82,19 & \\
\hline
\end{tabular}

Berdasarkan tabel 7 jumlah Skor keseluruhan pada tes siklus berjumlah 1315 yang berarti meningkat dari siklus II. Berdasarkan hasil penilaian siklus II, nilai rata-rata siswa yaitu sebesar 82,19 dengan kategori baik.

3) Observasi

Observasi yang dilakukan pada siklus II dilakukan oleh observer. Hasil observasi aktivitas guru dapat dilihat pada tabel berikut. 
Tabel 8. Hasil Observasi Aktivitas Guru Siklus II

\begin{tabular}{|c|c|c|c|}
\hline \multirow{2}{*}{ No. } & \multirow{2}{*}{ Aktivitas Guru } & \multicolumn{2}{|c|}{ Pertemuan } \\
\hline & & 1 & 2 \\
\hline 1 & $\begin{array}{l}\text { Meminta semua siswa memegang angklung, satu } \\
\text { orang satu buah angklung }\end{array}$ & $\sqrt{ }$ & $\sqrt{ }$ \\
\hline 2 & $\begin{array}{l}\text { Meminta siswa memegang angklung dengan teknik } \\
\text { yang benar }\end{array}$ & $\sqrt{ }$ & $\sqrt{ }$ \\
\hline 3 & $\begin{array}{l}\text { Mencek satu persatu siswa dalam hal teknik } \\
\text { memegang angklung dan membetulkan teknik kepada } \\
\text { siswa yang salah tekniknya }\end{array}$ & $\sqrt{ }$ & $\sqrt{ }$ \\
\hline 4 & $\begin{array}{l}\text { Mengomandoi siswa secara serentak membunyikan } \\
\text { angklung beberapa kali }\end{array}$ & $\sqrt{ }$ & $\sqrt{ }$ \\
\hline 5 & $\begin{array}{l}\text { Menyanyikan "Bubuy Bulan" baik notasi angkanya } \\
\text { maupun syairnya dan siswa mengikuti setelah guru }\end{array}$ & $\sqrt{ }$ & $\sqrt{ }$ \\
\hline 6 & $\begin{array}{l}\text { Memberikan contoh membunyikan angklung yang } \\
\text { kemudian diikuti oleh siswa dikelompoknya masing- } \\
\text { masing }\end{array}$ & $\sqrt{ }$ & $\sqrt{ }$ \\
\hline 7 & $\begin{array}{l}\text { Meminta siswa langsung memainkan angklung } \\
\text { dengan materi lagu "Bubuy Bulan" secara } \\
\text { berkelompok }\end{array}$ & $\sqrt{ }$ & $\sqrt{ }$ \\
\hline 8 & $\begin{array}{l}\text { Siswa diminta untuk memainkan lagu sesuai dengan } \\
\text { tempo yang ada di notasi angka tersebut }\end{array}$ & $\sqrt{ }$ & $\sqrt{ }$ \\
\hline 9 & $\begin{array}{l}\text { Menunjuk salah seorang siswa dari kelompok lain } \\
\text { untuk memandu atau menunjuk notasi angka di } \\
\text { whiteboard, secara bergantian }\end{array}$ & $\sqrt{ }$ & $\sqrt{ }$ \\
\hline 10 & $\begin{array}{l}\text { Mengomandoi kelompok secara bergantian } \\
\text { memainkan alat musik angklung }\end{array}$ & $\sqrt{ }$ & $\sqrt{ }$ \\
\hline \multicolumn{2}{|c|}{ Jumlah } & 9 & 9 \\
\hline \multicolumn{2}{|c|}{ Persentase } & $100 \%$ & $100 \%$ \\
\hline
\end{tabular}

Hasil observasi aktivitas siswa pada siklus II adalah sebagai berikut Tabel 9. Hasil Aktivitas Siswa Siklus II

\begin{tabular}{|l|l|c|c|c|c|}
\hline \multirow{2}{*}{ No. } & \multicolumn{1}{|c|}{ Aktivitas Siswa } & \multicolumn{2}{c|}{ Banyak Siswa } & \multicolumn{2}{c|}{ Persentase } \\
\cline { 3 - 6 } & & Pert. 1 & Pert. 2 & Pert. 1 & Pert. 2 \\
\hline 1 & $\begin{array}{l}\text { Memperhatikan penjelasan } \\
\text { guru secara detil tentang } \\
\text { teknik dan etika bermain } \\
\text { angklung }\end{array}$ & 14 & 16 & $87.5 \%$ & $100.0 \%$ \\
\hline 2 & $\begin{array}{l}\text { Memegang angklung dengan } \\
\text { benar }\end{array}$ & 12 & 14 & $75.0 \%$ & $87.5 \%$ \\
\hline 3 & $\begin{array}{l}\text { Percaya diri memainkan alat } \\
\text { musik angklung }\end{array}$ & 14 & 15 & $87.5 \%$ & $93.8 \%$ \\
\hline 4 & $\begin{array}{l}\text { Fokus dalam memainkan } \\
\text { angklung }\end{array}$ & 13 & 16 & $81.3 \%$ & $100.0 \%$ \\
\hline
\end{tabular}




\begin{tabular}{|l|c|c|c|c|c|}
\hline \multirow{2}{*}{ No. } & \multirow{2}{*}{ Aktivitas Siswa } & \multicolumn{2}{|c|}{ Banyak Siswa } & \multicolumn{2}{c|}{ Persentase } \\
\cline { 3 - 6 } & Pert. 1 & Pert. 2 & Pert. 1 & Pert. 2 \\
\hline 5 & $\begin{array}{l}\text { Kompak dengan kelompok } \\
\text { dalam memainkan angklung }\end{array}$ & 12 & 16 & $75.0 \%$ & $100.0 \%$ \\
\hline \multicolumn{2}{|c|}{ Persentase } & $81 \%$ & $96 \%$ & & \\
\hline
\end{tabular}

4) Refleksi

Pada siklus II peneliti melakukan refleksi pada tindakan yang telah dilakukan. Berdasarkan hasil pengamatan ditemukan beberapa hal yaitu ada tahap ini siswa perkelompoknya sudah mampu dikondisikan dengan baik. Guru sudah lebih leluasa memberikan komando dan siswa mengikuti dengan baik dan benar. Aba-aba dari guru adalah acuan bagi siswa untuk fokus pada permainan alat usik angklung yang mereka lakukan. Komando dari guru sangat menentukan konsentrasi mereka. Dan notasi angka yang ditulis dipapan tulis juga sangat membantu dalam proses penghapalan notasi angka untuk dibunyikan pada alat musik angklung. Berdasarkan hasil penilaian siklus II nilai rata-rata pada siklus II yaitu sebesar 82,19 dan masuk kedalam kategori "BAIK", maka penelitian tindakan dikatakan berhasil karena sudah memenuhi kriteria keberhasilan yaitu nilai rata-rata dalam kategori "Baik".

\section{Pembahasan}

Pada pelaksanaan kegiatan tindakan, siswa diminta memainkan alat musik angklung langsung dengan notasi lagu Bubuy Bulan tanpa menerangkan terlebih dahulu unsur-unsur musik. Siswa dibiasakan langsung menerapkan notasi yang sudah ditetapkan oleh peneliti untuk langsung dimainkan dengan alat musik angklung dan ini dilakukan secara berulangkali dengan kelompok. Hasil dari tindakan dengan metode pengajaran langsung ke alat musik ini menunjukkan adanya peningkatan pada tiap siklus yang dapat dilihat pada nilai rata-rata tiap siklus. Nilai rata-rata pra siklus adalah 63,44 dan pada siklus I mengalami peningkatan menjadi 77,31. Peningkatan hasil pada tiap siklus dapat dilihat dari nilai rata-rata pra siklus dan siklus I yang mengalami peningkatan sebesar 13,87. Peningkatan tersebut dihitung menggunakan cara yang sama dengan yang digunakan pada pra siklus dan siklus I. Berdasarkan hasil tindakan pada siklus I yang belum memenuhi kriteria keberhasilan, maka tindakan dilanjutkan pada siklus II. Pada siklus II diharapkan mengalami peningkatan dari siklus I. Ratarata nilai siklus I dan siklus II dihitung untuk melihat peningkatannya. Hasil peningkatan siklus I dan siklus II juga terlihat pada setiap siswa. Berdasarkan hasil tindakan pada siklus I yang belum memenuhi kriteria keberhasilan, maka tindakan dilanjutkan pada siklus II. Pada siklus II mengalami peningkatan dari siklus I. Nilai rata-rata siklus I dan siklus II mengalami peningkatan sebesar 4,88. Hasil peningkatan pra siklus, siklus I dan siklus II juga terlihat pada setiap siswa. Berikut adalah perolehan nilai siswa pada pra siklus, siklus I, dan siklus II.

Tabel 10. Perolehan Nilai Pada Setiap Siklus

\begin{tabular}{|c|c|c|c|}
\hline No & Pra Siklus & Siklus I & Siklus II \\
\hline 1 & 65 & 75 & 80 \\
\hline 2 & 80 & 85 & 85 \\
\hline 3 & 80 & 82 & 85 \\
\hline
\end{tabular}




\begin{tabular}{|c|c|c|c|}
\hline No & Pra Siklus & Siklus I & Siklus II \\
\hline 4 & 60 & 80 & 85 \\
\hline 5 & 80 & 80 & 85 \\
\hline 6 & 60 & 70 & 75 \\
\hline 7 & 55 & 75 & 80 \\
\hline 8 & 65 & 80 & 80 \\
\hline 9 & 65 & 80 & 85 \\
\hline 10 & 60 & 75 & 80 \\
\hline 11 & 50 & 85 & 85 \\
\hline 12 & 60 & 85 & 85 \\
\hline 13 & 50 & 75 & 80 \\
\hline 14 & 60 & 70 & 85 \\
\hline 15 & 65 & 70 & 80 \\
\hline 16 & 60 & 70 & 80 \\
\hline
\end{tabular}

Berdasarkan hasil yang didapat pada pra siklus ke siklus I dan siklus I ke siklus II, diuraikan secara singkat bahwa setelah menerapkan metode pembelajaran langsung keterampilan siswa kelas VIII.B dalam bermain angklung mengalami peningkatan.

\section{KESIMPULAN DAN SARAN}

Kesimpulan dalam penelitian ini yaitu penerapan metode pembelajaran langsungpada dapat meningkatkan keterampilan siswa memainkan alat musik angklungkelas VIII.B UPTD SMPN 5 Kecamatan Lareh Sago Halaban tahun pelajaran 2019/2020. Hal ini dapat ditunjukkan pada hasil pengamatan dan analisis yang dilakukan pada pra siklus, siklus I dan siklus II. Nilai rata-rata pada tiap tiap siklus mengalami peningkatan. Setiap peningkatan menunjukkan nilai yang signifikan, hal ini tentunya keberhasilan metode yang dipakai sangat membantu meningkatkan keterampilan bermain alat musik angklung.

Saran yang dapat dikemukakan yaitu:

1. Metode pembelajaran langsung dapat digunakan pada pembelajaran lain.

2. Peneliti selanjutnya juga bisa menambahkan variabel lain dalam penelitian terkait dengan metode pembelajaran langsung.

\section{DAFTAR PUSTAKA}

Amri, Sofan dan Ahmadi, Iif Khoiru. 2010. Proses Pembelajaran Kreatif dan Inovatif Dalam Kelas: Metode, Landasan Teoritis-Praktis dan Penerapannya. Jakarta: PT. Prestasi Pustakaraya

Kasmaja DS, Hadi.2014. Model Pembelajaran Langsung. Jakarta: Kencana Prenada Media Group

Rosyadi. 2012. Angklung: Dari Angklung Tradisional ke Angklung Modern. Patanjala Vol. 4, No. 1, Maret 2012: 26-40,

Trianto.2010.Mendesain Model Pembelajaran Inovatif-Progresif. Jakarta: Kencana Prenada Media Group 